\title{
Analysis of PV power future development possibilities
}

Vytautas Adomavičius,

\section{Mantas Kaminickas}

Department of Electrical Power Systems, Kaunas University of Technology, Studenty St. 48-205, LT-51367 Kaunas

E-mail: vytautas.adomavicius@ktu.lt
Numerous innovations, absence of fuel and fuel-related problems, excellent environmental characteristics and other economic and technical factors result in a permanent decline of PV systems cost and unprecedented growth of photovoltaic markets. Because of this, PV energy production technologies are becoming economically viable even in the Northern countries where the annual solar irradiation on the horizontal surface is around $900-1100 \mathrm{kWh} / \mathrm{m}^{2}$. New circumstances allow reconsideration of PV systems viability for electricity production in high latitude countries not excepting the Baltic States. This paper provides a review of broad data on global development trends for solar power plants, including countries where solar irradiations are moderate. Advantages of PV systems development are justified by taking into account electricity generation costs, external costs and positive impact on climate change mitigation. Further reduction of PV systems cost is reasoned by describing recent innovations that will have a major impact on a new decrease of PV modules prices. The paper also discusses possible ways that could allow minimizing of PV power plants integration costs by reduction of expenditures for power balancing. The provided data reflect that good results in integration costs reduction can be achieved by combining several renewable energy sources like wind, solar and hydro in proper ratios. Finally, the presented data and their analysis indicate that PV power plants could definitely take a certain part in the future electricity generation mix in high latitude countries due to its wide accessibility, economic efficiency, maturity and environmental benefits.

Key words: renewable energy, PV power plants, trends of development, generation costs, integration costs, external costs, climate change

\section{INTRODUCTION}

The main trend of the world energy sector is presently a rapid transition from the fossil fuels to the renewable energy sources (RES). Development of the RES-based heat and power production in the world experienced a sweeping growth during the last decade. It is especially evident in the power production sector. Many countries already con- sume substantial quantities of electric power, which is produced in power plants running on renewable energy sources. About 50 countries in the world presently have shares of green origin power from 50 to $100 \%$ of the consumed power $[1,2]$. About 30 of them already have achieved shares from 80 to $100 \%$ and 22 of them from 90 to $100 \%[1,2]$. Shares of electricity production from renewables in the world's leading countries and 
the Baltic Region are presented in Table 1. The table was compiled from the data given in references $[1,2]$ for the years 2012-2013.

The main renewable energy sources exploited for power production during the last decade were wind, solar energy, traditional hydro energy and biomass. The main reasons promoting the green power production development are aspirations of the environment pollution reduction, urgency of the climate change process mitigation, economic benefits, endeavour of energy independence, and simply because the RES-based power production technologies are becoming more and more competitive even without paying attention to their significant environmental advantages. The brisk power price reduction process is especially typical for photovoltaic (PV) power plants. This former very expensive power production technology is becoming one of the most cost-efficient processes. Currently it is reaching the grid parity in various countries. The time of this milestone achieving depends mostly on the price of electricity in a certain country and on its solar energy resources.
This technology on its sixtieth birthday (April 25, 1954, Bell Labs in Berkley Heights, N. J.) is becoming a major contender for leadership in the electricity production sector due to the universal availability of solar energy resources, enormous untapped potential, cost-effectiveness, maturity and environmental advantages. The estimated cost of the first solar module was 286 US $\$ / W$, presently it makes up about $0.75 \mathrm{US} \$ / \mathrm{W}$, and the next target of some companies is approximately twice lower [3, 4].

Step-by-step environmental aspects of energy production technologies are being taken into account as well. Taxes for mitigation of greenhouse gas emissions' consequences were introduced in the Northern Europe countries since the last decade of the twentieth century.

Some countries in the world, as EU countries, Taiwan, Sweden and other, have already introduced carbon taxes at the domestic level. Values of carbon emission taxes for a tonne of $\mathrm{CO}_{2}$ equivalent are very different: $7 € /$ tonne in the EU countries, 156 US\$/tonne in Sweden,

Table 1. Shares of electricity production from renewables in the world's leading countries and the Baltic Region

\begin{tabular}{|c|c|c|c|c|c|}
\hline \multicolumn{2}{|l|}{ Europe } & \multicolumn{2}{|c|}{ Africa } & \multicolumn{2}{|c|}{ America } \\
\hline Country & $\%$ & Country & $\%$ & Country & $\%$ \\
\hline Iceland & 100 & Lesotho & 100 & Paraguay & 100 \\
\hline Norway & 98 & Mozambique & 100 & Honduras & 97 \\
\hline Georgia & 86 & Zambia & 100 & Brasilia & 96 \\
\hline Albania & 85 & Congo DR & 100 & Guatemala & 94 \\
\hline Austria & 74 & Angola & 97 & Costa Rica & 93 \\
\hline Portugal & 70 & Somalia & 96 & Belize & 91 \\
\hline Latvia & 62 & Tanzania & 90 & Colombia & 86 \\
\hline Sweden & 61 & Uganda & 90 & Venezuela & 73 \\
\hline Switzerland & 60 & Rwanda & 87 & El Salvador & 63 \\
\hline Denmark & 48 & Malawi & 86 & Canada & 63 \\
\hline Montenegro & 48 & Congo & 82 & Peru & 57 \\
\hline Croatia & 46 & CAR & 81 & \multicolumn{2}{|c|}{ Oceania } \\
\hline Finland & 40 & Cameroon & 77 & N. Zealand & 76 \\
\hline Asia & & Ghana & 75 & Papua N. G. & 39 \\
\hline Bhutan & 100 & Kenya & 68 & \multicolumn{2}{|c|}{ Baltic Region } \\
\hline Nepal & 100 & Sudan & 63 & Belarus & 1 \\
\hline Tajikistan & 98 & Mali & 58 & Estonia & 12 \\
\hline Laos PDR & 93 & Madagascar & 52 & Lithuania & 14 \\
\hline Kirgizia & 91 & Gabon & 46 & Poland & 11 \\
\hline \multicolumn{6}{|c|}{ China, European Union and World } \\
\hline China-2012 & 19.2 & EU-2013 & 23.8 & World-2012 & 22 \\
\hline
\end{tabular}


61.8 US\$/tonne in Taiwan, etc. UNEP and many other international organizations are urging introduction of carbon tax globally. Tax about 20$70 \mathrm{US} \$$ /tonne for $\mathrm{CO}_{2}$ equivalent is currently being issued. The income from this tax is intended to be used for compensation of damages made by the global climate change induced disasters and for covering of the huge adaptation costs due to the climate change.

The Intergovernmental Panel on Climate Change (the scientific intergovernmental organization acting under the auspices of the UN; www.ipcc.ch) warned that the world must triple the use of clean renewable energy immediately and enhance usage of carbon free nuclear power in order to avoid the worst ravages on the Earth what is already happening in the world with rising strength and frequency [5]. Pollution induced natural megadisasters, which are already happening in the world every year, evidently show that climate change is not a distant threat. It is a severe reality which is very harmful to the mankind right now [6]. Therefore, ignorance, indifference, dormancy and even antagonism of some decision-makers in regard of environment pollution can be very destructive to us and especially to the future generations.

In this article, a review and analysis of photovoltaic power production growth peculiarities in the past years and prospects of further development were performed on purpose to find out solid and convincing arguments for reasoning of the decisions regarding the PV power production targeting to be taken for future years. Possibilities of PV power production development in Lithuania and other high latitude countries were analysed in the global and European context taking into consideration local solar energy resources.

\section{CURRENT SITUATION}

\section{Present PV power development rates}

Cumulative capacity of operating PV power plants in the world was rapidly increasing during the last three decades, but substantial growth of the capacities started a skyrocketing spring up after the year 2007, when prices of the photovoltaic modules began dropping dramatically. Nowadays, photovoltaic power production is the fastest growing energy production technology in the world that currently represents over $35 \mathrm{GW}$ capacity growths per year [7]. Cumulative capacity of operating $\mathrm{PV}$ power plants in the world in 2013 achieved over 137 GW (increased 35\% per one year) while according to some early prognoses the expected target was only $10 \mathrm{GW}$ by this time (thus, this primary target was exceeded around 14 times). It is estimated that over 53 million tons of $\mathrm{CO}_{2}$ emissions are saved each year [7] because of these PV power plants operation. These figures show that PV power production technologies already have a considerable impact on power production sector output and in reduction of environment pollution. According to the dominant predictions, they will play a major role in the world's energy mix during decades of the nearest future [7-10]. Therefore, more detailed knowledge about these promising technologies could be useful before taking decisions regarding the possibilities of their development in the Baltic countries. Situation and trends of PV power production development in the world and EU countries, some promising already proved innovations and technical potentials of solar radiation in the regions under consideration are worth taking a closer look.

Importance of the PV power production technology for power engineering of the 21th century can be substantiated by many facts. It can also be extents of installations of PV power plants in Europe and the world. Power generation capacities installed in the EU countries by various power production technologies during the years 2000-2012 are depicted in Fig. 1 [7].

The fundamental message from Fig. 1 is that PV power plants (PVPP) became one of the leading technologies for power production in the first decade of the 21 st century and superiority of all renewable energy technologies for power production is more than evident when some technologies based on the fossil fuel experienced significant shrinking due to the decommissioning of many plants running on coal, nuclear fuel and fuel oil.

Trends of the same character and even substantially strengthened can be noticed in Fig. 2, where total power production capacities installed per 2012 in the EU27 are depicted by the type of technologies [7]. 


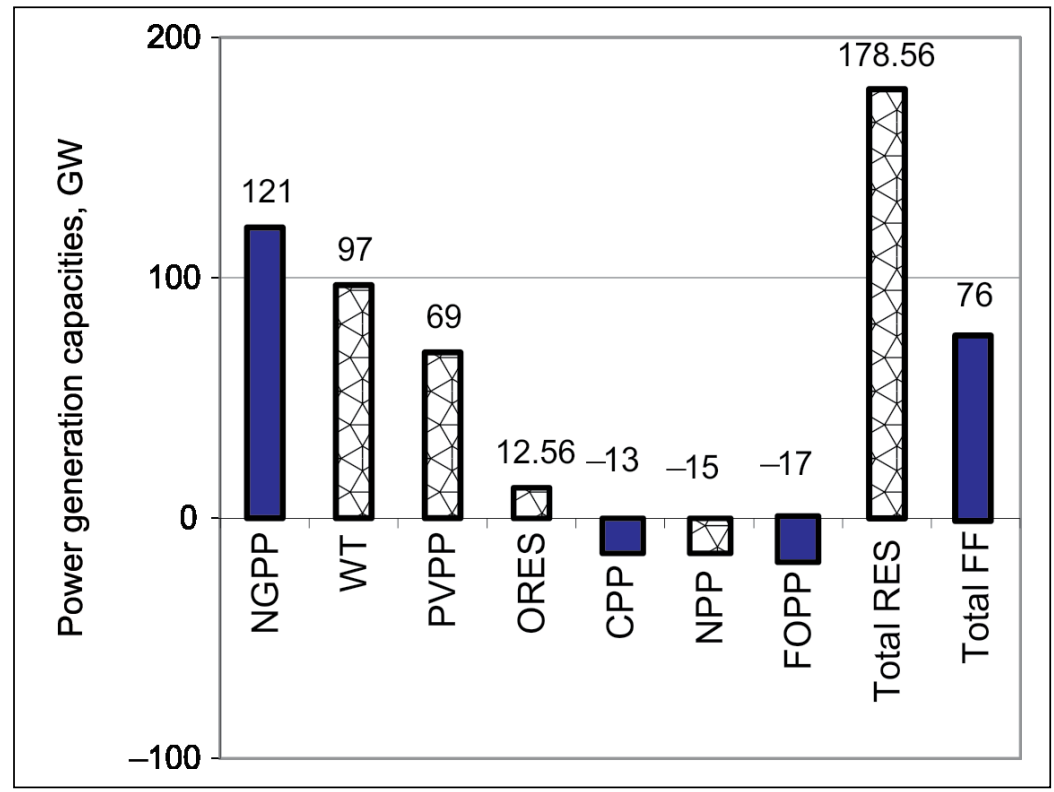

Fig. 1. Power generation capacities installed in the EU countries by the technologies during the years 2000-2012: NGPP - CHP plants running on natural gas, WT - wind turbines, PVPP - photovoltaic power plants, ORES - all other RES-based power plants, CPP - coalbased power plants, NPP - nuclear power plants, FOPP - power plants running on fuel oil, Total RES - total capacity of RES-based power plants, Total FF - total capacity of fossil fuels-based power plants [7]

As it is noticeable in this figure, the rooftop PV power plants and utility-scale PVPP combined together were the absolute leader among all technologies in 2012. Other RES-based power production technologies were appearing perfectly as well.

Smaller total installed capacities of other RES-based power production technologies in
Fig. 2 are indicated as ORES (other RES). They include biomass-based power production technologies (1.295 GW), offshore WT (1.166 GW), concentrated solar power plants $(0.833 \mathrm{GW})$, hydro electric power plants ( $0.266 \mathrm{GW})$, CHP plants running on waste (50 MW), wave and tidal power plants (6 MW) and geothermal power plants (5 MW). The negative sign (minus) at the value

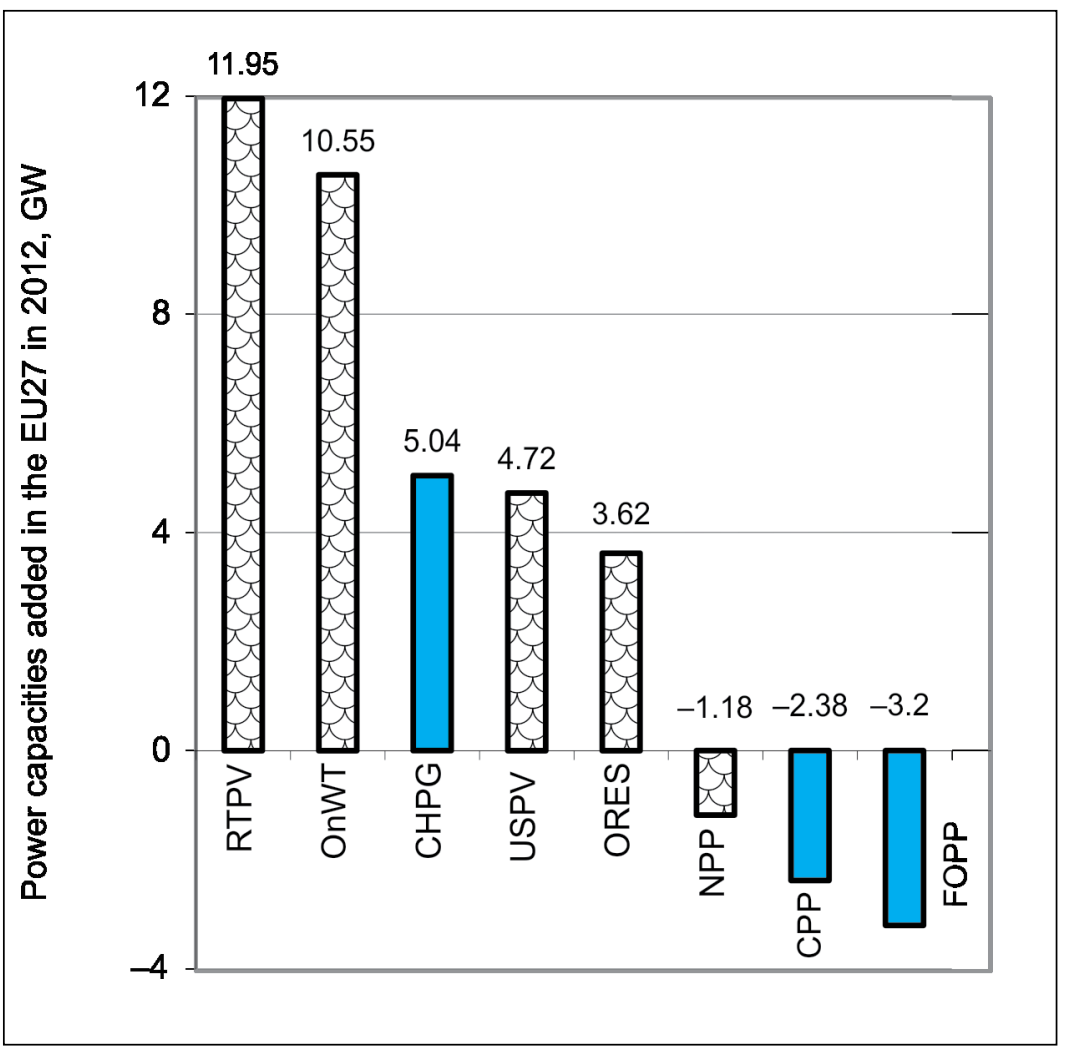

Fig. 2. Total power production capacities installed in the EU27 in 2012 by the power production technologies: RTPV - rooftop PV power plants, OnWT - onshore wind turbines, CHPG - combined heat and power plants running on natural gas, USPV - utility-scale photovoltaic power plants, ORES - all other RES-based power plants, NPP - nuclear power plants, CPP - coal-based power plants and FOPP - power plants running on fuel oil [7] 
of a certain capacity means that the total installed power of this technology decreased in this case in the EU27 due to the decommissioning of some power plants. This picture also shows absolute domination of the RES-based power production technologies $(+30.84 \mathrm{GW})$ against fossil fuel based technologies, which significantly shrank in total $(-1.72 \mathrm{GW})$.

Analysis of PV power production development in the EU countries shows that some European countries like Belgium, Czech Republic, Romania, Austria, Denmark and other, which have the same or similar solar energy resources like Lithuania and other Baltic countries, have already (2013) achieved good results in this area. Extent of installations of the PV power production capacities in specific European countries is presented in Table 2, which is compiled from various sources [11-14].

Figures in Table 2 show striking differences between the cumulative capacities of PVPP installed in the Baltic countries and in some other EU countries, solar irradiation data of which are not highly different. The data of solar irradiation indicated in this table in many cases differ only about $0-20 \%$ when cumulative overall capacities of installed PV power plants and shares of the produced solar power in regard to the total consumed power differ many times. The latest data show that the total installed capacity of PVPP in the Baltic countries makes up only about $70 \mathrm{MW}[11,13,14]$. This is a relatively small capacity, which compared to the total capacity $80 \mathrm{GW}$ installed in the EU27 is showing that this market is still in its infancy in the Baltic Region, and its pace of development is slow.

However, the examples of Belgium, which has already $3 \mathrm{GW}$ of photovoltaic installations, and other EU countries that are receiving similar irradiations from the sun, demonstrate that photovoltaic power production under presently existing economic, technical and environmental factors has a good potential for development in the Baltic countries as well.

Maturity of PV power production technologies also shows the following indicator: annual average PV contribution to electricity consumption in some EU countries already makes up 3-7\% and maximum instantaneous contribution is from 3.5\% to 9\% (Belgium, Bulgaria, Czech Republic, Germany, Italy and other countries) [1].

But this is only the beginning because PV power production is a rather young technology, the development of which began just sixty years ago. Meanwhile, wind energy, solar heat energy, hydro energy and fuel firing technologies exist already for thousands of years. Already known and approved innovations as well as bold predictions show that the present stage of the development of PV technologies is far from being unexceptionable.

Table 2. Extent of installation of the PV power production capacities in specific European countries in 2013

\begin{tabular}{|c|c|c|c|c|}
\hline \multirow{3}{*}{ Country } & \multirow{2}{*}{$\begin{array}{l}\text { Annual irradiation on the } \\
\text { horizontal surface }\end{array}$} & \multicolumn{2}{|c|}{ Cumulative capacity of PV power plants } & \multirow{2}{*}{$\begin{array}{l}\text { Average share of to- } \\
\text { tal consumed power }\end{array}$} \\
\hline & & Overall & Per capita & \\
\hline & $\mathrm{kWh} / \mathrm{m}^{2}$ & GW & W & $\%$ \\
\hline Germany & $950-1300$ & 36.013 & 447 & 5.3 \\
\hline Belgium & $950-1050$ & 3.000 & 272 & 3.45 \\
\hline UK & $800-1200$ & 2.900 & 46 & 0.81 \\
\hline Czech Republic & $1030-1130$ & 2.160 & 206 & 3.4 \\
\hline Romania & $1200-1400$ & 1.100 & 52 & 2.2 \\
\hline Bulgaria & $1450-1550$ & 1.000 & 137 & 3.8 \\
\hline Netherlands & $950-1050$ & 0.650 & 39 & 0.53 \\
\hline Ukraine & $1100-1380$ & 0.616 & 14 & 0.57 \\
\hline Austria & $1100-1200$ & 0.580 & 69 & 1.2 \\
\hline Denmark & $950-1000$ & 0.532 & 96 & 1.67 \\
\hline Slovakia & $1050-1250$ & 0.524 & 97 & 1.65 \\
\hline Lithuania & $950-1070$ & 0.068 & 24 & 0.45 \\
\hline Latvia (2012) & $950-1070$ & 0.0015 & 0.7 & 0.01 \\
\hline Poland (2012) & $1020-1120$ & 0.034 & 0.1 & 0.00 \\
\hline Estonia (2012) & $950-1000$ & 0.0002 & 0.1 & 0.00 \\
\hline
\end{tabular}


Evident usefulness of the published innovations and patents also show that further successful development of these technologies accompanied by substantially better technical end economic efficiency indicators is highly believable.

\section{Global technical potential of solar radiation}

Apart from other advantages mentioned above, solar energy has the highest energetic potential in our planet and the very best accessibility among all renewable energy sources. Global yearly technical potential of direct solar energy is compared to global technical potentials of other renewable energy sources and global yearly electrical and heat energy demands in Table 3 [15-17].

According to the data presented in Table 3, the maximal global yearly technical potential of direct solar energy exceeds the total global yearly potential of all the rest renewable energy sources by around 20 times, and this potential covers all global yearly primary energy demands approximately 100 times. The maximal global technical potential of wind energy makes up only about one percent of the direct solar energy global maximal technical potential.

\section{FACTORS IMPACTING FURTHER PV POWER PRODUCTION DEVELOPMENT}

\section{Environmental advantages}

Installation of PV and other RES-based power plants in the substantial scale has a very important and positive impact on the reduction of en- vironment pollution and mitigation of the global climate change process [15-18]. It can be substantiated by comparing the carbon intensity of various power production technologies. The average carbon intensity indicators of power generation by various power plants are shown in Fig. 3 $[6,15]$.

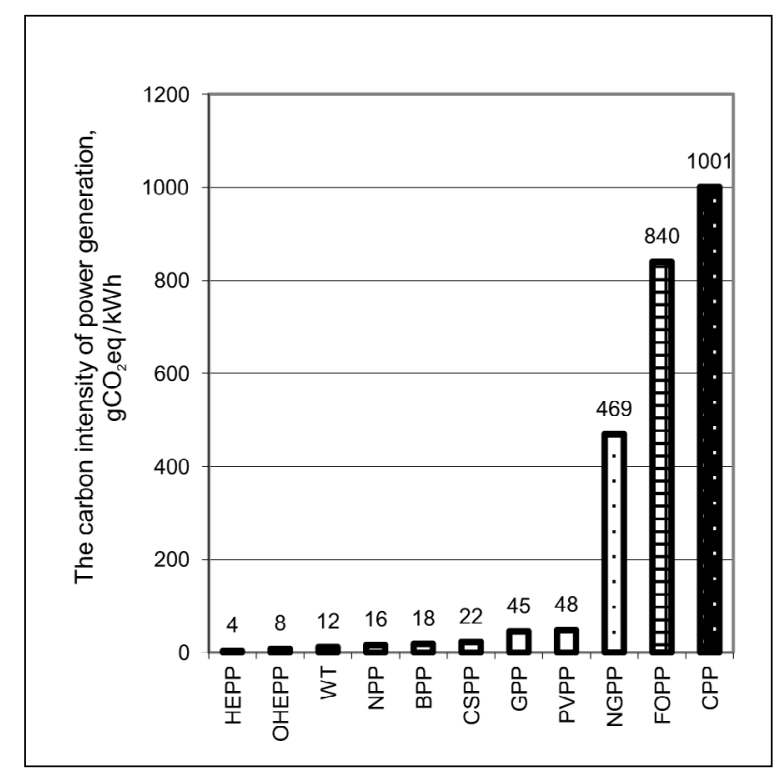

Fig. 3. The average carbon intensity of power generation by the technologies: HEPP - hydro electric power plants, OHEPP - oceanic HEPP (wave and tidal), WT - wind turbines, NPP - nuclear power plants, BPP - biomass-based power plants, CSPP - concentrated solar power plants, GPP - geothermal power plants, PVPP - photovoltaic power plants, NGPP - power plants running on natural gas, FOPP - power plants running on fuel oil, CPP - coal-based power plants, LPP - lignite-based power plants [6, 15]

Ta ble 3. Comparison of global yearly technical potentials of renewable energy sources and global yearly energy demands [15-17]

\begin{tabular}{|c|c|c|c|c|}
\hline \multirow{2}{*}{ Renewable energy sources } & \multirow{2}{*}{ Unit } & \multicolumn{2}{|c|}{ Global technical potential } & \multirow{2}{*}{$\begin{array}{c}\text { Total global energy } \\
\text { demands } 2008\end{array}$} \\
\hline & & Min & Max & \\
\hline \multicolumn{5}{|c|}{ Electricity production } \\
\hline Solar energy & \multirow{5}{*}{$\mathrm{EJ} / \mathrm{yr}$} & 60 & 1200 & \multirow{5}{*}{61} \\
\hline Geothermal energy & & 118 & 1109 & \\
\hline Wind energy & & 85 & 580 & \\
\hline Ocean energy & & 7 & 331 & \\
\hline Hydro energy & & 50 & 52 & \\
\hline \multicolumn{5}{|c|}{ Heat energy production } \\
\hline Geothermal energy & $\mathrm{EJ} / \mathrm{yr}$ & 10 & 312 & 164 \\
\hline \multicolumn{5}{|c|}{ Primary energy supply } \\
\hline Direct solar energy & \multirow{2}{*}{$\mathrm{EJ} / \mathrm{yr}$} & 1575 & 49837 & \multirow{2}{*}{492} \\
\hline Biomass energy & & 50 & 500 & \\
\hline & & $78 \mathrm{TWh}$ & & \\
\hline
\end{tabular}


As it is reflected in Fig. 3, all RES-based power production technologies have a huge advantage over the technologies based on fossil fuels. Currently, PV power plants have the highest carbon intensity among the power plants running on renewables - $48 \mathrm{~g} / \mathrm{kWh}$ of $\mathrm{CO}_{2}$ equivalent [6]. This figure is the weighted average of carbon intensity of various technologies presently used for the PV cells production (mono-crystalline silicon, multi-crystalline silicon, amorphous silicon, CdTe and CIGS).

The most carbon intensive technology of PV cells production is presently based on the mono-crystalline silicon (carbon footprint $2728 \mathrm{~kg} / \mathrm{kWp}$ of $\mathrm{CO}_{2}$ equivalent) and the least intensive technology is based on CdTe (carbon footprint $574 \mathrm{~kg} / \mathrm{kWp}$ of $\mathrm{CO}_{2}$ equivalent). Carbon intensity of the mono-crystalline silicon PV cells is high because production of crystalline silicon ingots, as it is widely known, requires consuming a lot of power. However, innovations make possible a significant reduction of silicon amounts for the PV cells production.

The International Company Solar Bankers developed a new technology, which allows reduction of silicon for the PV cells production by $90 \%$. Thus, carbon intensity indicators for the PV power plants will soon have to be reduced. But even the currently existing carbon intensity indicator for the PVPP $\left(\mathbf{4 8} \mathbf{~ g} / \mathbf{k W h}\right.$ of $\mathrm{CO}_{2}$ equivalent) is by far smaller than the present carbon intensity indicator for the global electricity mix, which makes up over $\mathbf{6 0 0} \mathrm{g} / \mathbf{k W h}$ of $\mathrm{CO}_{2}$ equivalent (see Fig. 3).

\section{Economic aspects and benefits}

Cost of electricity produced by a power generation plant of any type in general depends on the power generation costs and on the power integration costs (costs of integration into the power system). External costs and sustainability of any power generation technology have to be taken into account as well because the exact and correct evaluation of these technologies presently became very important in many aspects.

Generation cost of electricity produced by one or another power generation plant and calculated as the average full life-cycle cost for the energy unit (kWh) is called the levelized cost of electricity (LCOE). LCOE is calculated by evalu- ating all incurred fixed and variable costs related to electricity production. The following formula is used for this purpose $[19,20]$ :

$$
C_{L E}=\frac{I_{0}+\sum_{i=1}^{n} \frac{M_{i}+F_{i}}{(1+r)^{i}}}{\sum_{i=1}^{n} \frac{E_{i}}{(1+r)^{i}}},
$$

where $C_{L E}$ is the levelized cost of electricity, EUR/ $\mathrm{kWh}$,

$I_{0}$ - investment costs, EUR,

$M_{i}$ - expenditures on operation and maintenance per year “ $i$ ", EUR,

$F_{i}$ - expenditures for fuel per year “ $i$ ", EUR,

$r$ - real interest rate,

$n$ - the designed number of lifetime years,

$i$ - the year of lifetime $(i=1,2,3, \ldots, n)$,

$E_{i}$ - electricity produced per year " $i$ ", kWh.

Evaluation of economic efficiency and rating of any power production technology can be based on comparison of their values of LCOE and variables used in Formula (1).

Investment costs for PVPP prominently depend on the time as no other power production technology, but good news is that it can be identified as a rather brisk decrease of the costs in this case. This and the main other indicators evaluating the efficiency of PV power production by the roof-top technology are compared with the corresponding indicators of power plants based on fossil fuels (FFPP) in Table 4, which is compiled of data presented in references [21-23].

Presently, investment costs of PVPP are among the lowest, and they continue dropping towards the leading position among the power production technologies. Installation, exploitation and dismantlement of $\mathrm{PV}$ power plants after the end of lifetime are very simple and do not require especially skilled specialists.

Operation and maintenance costs consist of fixed expenditures (staff salaries, taxes, insurance, rates, etc.) and variable expenditures (expenditures for repair, maintenance, removing of waste, materials, chemicals, etc.). These costs for PVPPs are among the lowest in the category of power generation plants because they have no rotating or moving parts and do not require many employees, especially in case of the small-scale roof-top power plants, which make up a major part of all PVPPs. 
Ta ble 4. Generation costs, external costs and sustainability of the roof-top PVPP in comparison with the same indicators of power plants based on fossil fuels [21-23]

\begin{tabular}{|c|c|c|c|c|}
\hline \multirow{2}{*}{ No. } & \multirow{2}{*}{ Parameter } & \multirow{2}{*}{ Unit } & \multicolumn{2}{|c|}{ Comparison of technologies } \\
\hline & & & PVPP & FFPP \\
\hline \multicolumn{5}{|c|}{ Power generation costs } \\
\hline 1. & Investment expenditures & $\mathrm{EUR} / \mathrm{kW}$ & $1000-1500$ & $700-6000$ \\
\hline 2. & Operation and maintenance & EURct/kWh & $\sim 0.5$ & $0.5-1.0$ \\
\hline 3. & Expenditures for fuel & EURct/kWh & 0 & $0.5-4.0$ \\
\hline \multicolumn{5}{|c|}{ External costs } \\
\hline 1. & Impact on human health & EURct/kWh & 0.21 & $0.28-2.74$ \\
\hline 2. & Impact on climate change & EURct/kWh & 0.24 & $1.84-3.89$ \\
\hline 3. & Impact on environment & EURct/kWh & 0.01 & $0.06-0.44$ \\
\hline 4. & Impact of radionuclides & EURct/kWh & 0 & $0-0.001$ \\
\hline 5. & Total negative impact & EURct/kWh & 0.46 & $2.19-4.49$ \\
\hline \multicolumn{5}{|c|}{ Assessment of sustainability of power generation technologies } \\
\hline 1. & Score after the indifferent scenario & Points & 0.75 & $0.67-1.75$ \\
\hline 2. & Score after the environmental scenario & Points & 0.50 & $0.54-1.67$ \\
\hline 3. & Score after the economic scenario & Points & 1.20 & $0.72-1.62$ \\
\hline 4. & Score after the social scenario & Points & 0.47 & $0.78-2.14$ \\
\hline
\end{tabular}

PVPPs have a very solid advantage regarding the expenditures for fuel - solar radiation and its delivery is always free from payment and from all related troubles.

\section{External costs}

External costs are being calculated for the purpose of fair and proper comparison of various power production technologies. Energy-related emissions and all incurred losses and damages associated with different power production technologies are important in this case and have to be taken into account. Usually, this can be done by finding external costs that include two main components [22]:

- Climate change damage costs associated with $\mathrm{CO}_{2}$ emissions (Fig. 3),

- Damage costs associated with other air polluting elements (heavy and radioactive metals, $\mathrm{NO}_{\mathrm{X}}, \mathrm{SO}_{2}, \mathrm{NH}_{3}$ ) that have a negative impact on health, crops and our environment.

External costs for power production technologies were thoroughly researched and evaluated in around ten projects of the EU scientific programmes FP4-FP7 in the period 1994-2012. Results of these researches were analysed, corrected taking into account power production particularities in Lithuania, and presented in reference [22]. Some values of external costs of the roof-top PVPP and the power plants running on fossil fuels are presented in Table 4 for their comparison in this aspect.

The data presented in Table 4 show evident superiority of the roof-top PVPP technology against fossil fuels power stations when impact on human health is being evaluated: roof-top PV power plants have a negative impact on our health estimated 0.21 EURct/kWh when this indicator for the fossil fuel power stations varies from $\mathbf{0 . 2 8}$ to 2.74 EURct/kWh [22].

Similar cost distribution trends are retained in the case of impact on climate change: power generated in the roof-top PVPP incurs an economically expressed negative impact on climate change 0.24 EURct/kWh while the same indicator for the power plants running on fossil fuels varies from 1.84 EURct/kWh up to 3.89 EURct/ kWh (the last value is for the CHP power stations running on lignite) [22]. Coming back to Fig. 3, it can be confirmed that PV energy production technologies have a substantially smaller impact on climate change than power plants running on fossil fuels.

According to the European scientists and reference [22], the impact on environment of roof-top PVPP is also many times less harmful (0.01 EURct/kWh) than power plants running on fossil fuels (0.06-0.44 EURct/kWh). Only 
impact of radionuclides on human health in both cases is more or less comparable.

Thus, it can be concluded on the basis of the given above data that electricity generated in the $\mathrm{PV}$ power plants has approximately from 5 to 10 times smaller total external costs than the same amount of energy generated in fossil fuel power stations. This should be counted in as well when electricity generation technologies are compared and chosen for implementation.

\section{Sustainability of technology}

Assessment of sustainability of various electricity generation technologies was carried out by the Lithuanian Energy Institute. Evaluation of the technologies sustainability was based on the multi-criteria analysis and on references dated mostly in 2004-2009. Integrated indicators were calculated for the assessment of various technologies. Environmental, social and economic criteria were taken into consideration. Every criterion was comprised of four or five indicators. All technologies were assessed by evaluating their impact on the sustainable development. Some results of the analysis [23] regarding the roof-top PVPP and FFPP are presented in Table 4 (the lower integrated indicator is better). The main finding of the analysis described in reference [23] is the determination of PVPP and other renewable energy technologies for power production as the best in regard of the sustainability point of view. PVPP scored a little bit worse (1.2 points, see Table 4 ) only in the case of economic scenario when priority is given to the economic indicators. However, time is going in favour of the PV technologies and presently this evaluation must be updated significantly lower because installation costs of PVPP dropped dramatically during the past five years. Apart from this, environmental and social scenarios are presently much more relevant because of the costly consequences of global warming and high unemployment rates, especially in southern countries of the European Union. Some gains in the case of choosing an economic scenario can induce huge losses caused by megadisasters, which are related to global warming due to the neglecting of environment pollution.

\section{Integration costs}

Integration of PV power systems and other variable renewable power systems (e. g., wind tur- bines) into the public grid incurs some negative consequences and additional costs to the abovementioned power generation costs (LCOE). But there are some possibilities to reduce the integration costs of variable renewable power plants. They will be discussed below.

Costs of power integration into the grid of the power system consist of profile costs, short-term power balancing costs and grid-related costs.

Profile costs of intermittent power sources integration derive from the necessity of application of costly large capacitive power plants (mostly thermal) for power balancing. Therefore, the full-load operation of these power plants and their efficiency can decrease rather significantly because they must operate in the mode of constant adjusting of their capacities in order to keep the power balance in the public grid.

Short-term power balancing costs are related to a variable nature of the PV power plants (as well as wind power plants). They derive from the insufficient accuracy of the solar radiation or wind speed prognoses for the next day. Therefore, the additional expenditures are incurred because some additional measures and preparations are necessary in order to arrange smooth integration of the intermittent power into the power system.

Total power balancing costs in the $\mathrm{EU}$ are evaluated around 1.0 EURct/kWh [24] independently on the origin of the intermittent power sources. In Lithuania we have not yet integrated substantial PV power capacities in the power system, but, in principle, the type of an intermittent power source has no significant impact on power balancing technology or cost. The additional power balancing costs due to the operation of wind power plants and wind farms in the Lithuanian power system are estimated about 1.0 LTLct/ $\mathrm{kWh}$ (or about $0.3 \mathrm{EURct} / \mathrm{kWh}$ ).

Grid-related costs mostly come into play due to the necessity of transmission of the power generated by integrated PV plants. It can be the case when PV power plants have large scales and bulk of the produced power is not consumed locally. Some additional grid related costs of the intermittent power integration can derive as well if the grid constrains increase due to the integration.

Some losses can be incurred in cases when rates of PV power plants integration in the power system are very high (25-50\%). This can happen if 
power produced by the PV systems cannot be fully supplied and consumed in the grid and when power storage capacities in the system are insufficient. This case is hardly possible in Lithuania due to the operation of the powerful Kruonis Pumped Storage Power Plant.

\section{Impact of total PV capacity on balancing costs} Installation of the PV power plants is expedient and desirable not only due to their good environmental characteristics and economic benefits but also because of the necessity to have proper ratios between the total powers of intermittent power generation facilities in the power system. Optimal matching of these total powers can significantly reduce the necessary reserve capacities of electricity generators in the power system and, consequently, reduce the expenditures of power balancing to a certain extent in the long-term perspective (per year). This possibility can be realized by taking into account regularities of power production by all intermittent power plants operating in the power system.

Regularities of the average daily power generation productivity alterations of German photovoltaic power plants and wind turbines depending on the month are shown in Fig. 4 [25] (original source - EEX - European Energy Exchange AG).
This figure shows that the average daily power production indicator of wind turbines (measured in $\mathrm{Wh} / \mathrm{W}$ per day - the produced energy in Wh by one installed $\mathrm{W}$ per day) differs around three times depending on the month of the year. If the cumulative capacity of WTs in the power system is substantial, significant capacities of reserve power are necessary in this case in summer months.

However, as it is evident from Fig. 4, if the integrated cumulative capacity of the PVPPs is sufficient in the power system, variations of the resulting power of both intermittent power sources $(\mathrm{WT}+\mathrm{PV})$ can be significantly reduced (see the bold curve). It allows concluding that in the case when the intermittent power sources in the country's power systems consist only of wind and solar power plants, the best ratio between the total installed capacity of wind turbines and PV power plants should be around 1:1 in order to have more or less equal total intermittent power in the system every month.

Total capacities of hydro electric power plants and power plants running on biofuel also have to be taken into account if they are considerable (we include biomass-based power plants here because they are producing substantially less electricity in the summertime after the heating season). Thus, proper sizing of total capacities of intermittent

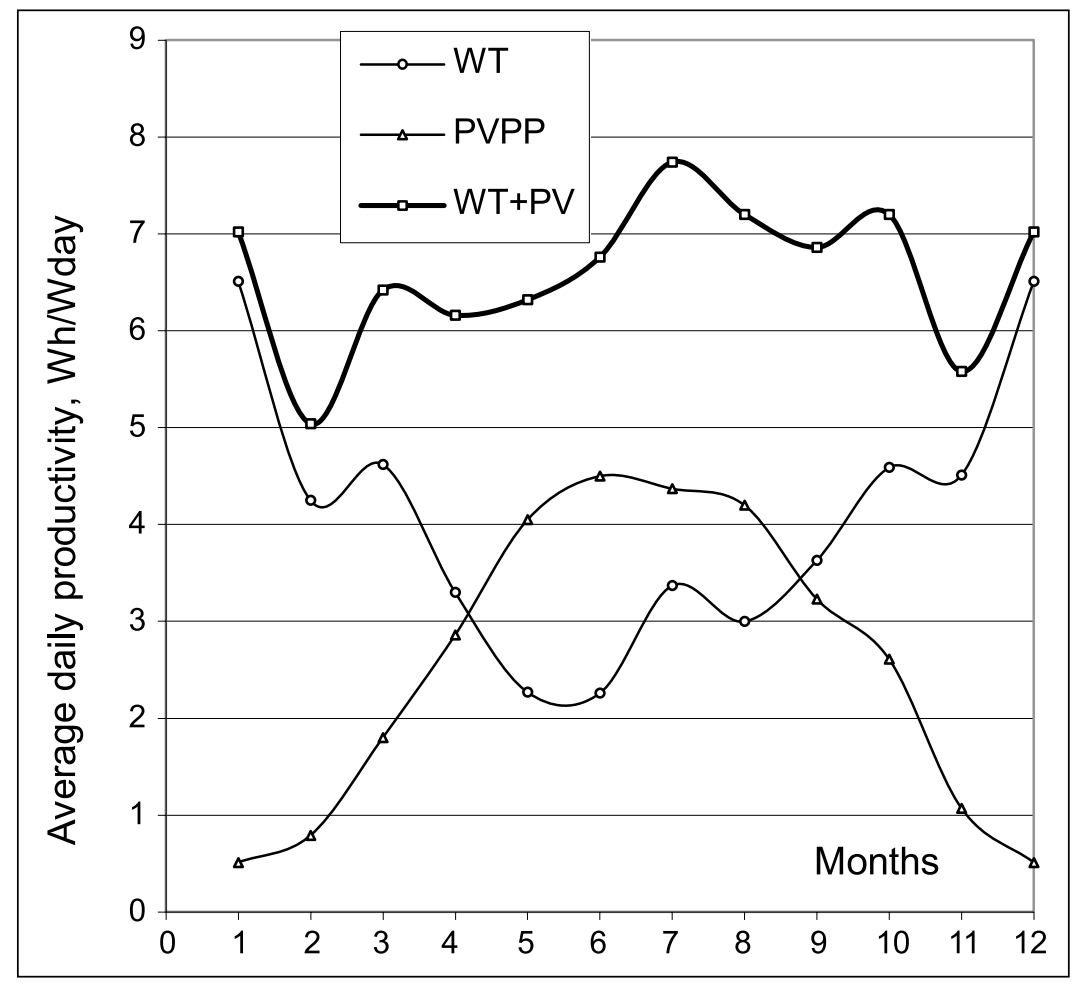

Fig. 4. The average daily power generation productivity of German PV power plants and wind turbines (WT) depending on the month calculated for the period from $01 / 2012$ to $12 / 2013$ [25] 
renewable energy power plants could allow minimizing the capacities of adjustable power sources kept in the power system for power balancing purposes. Choosing the right total capacity of the PV power plants can be the best option for optimal adjusting of total capacities of intermittent renewable energy power plants operating in the power system. It can be based on the following reasons: technical potentials of hydro electric power plants as well as biogas-based power plants are low in many countries and the total capacity of power plants running on biofuels is determined mostly by the demands for space heating. Only wind and PV power plants could be the main players, but cumulative capacities of wind power plants already have substantial values in many countries. More detailed researches are necessary in this area in order to solve this problem of the optimal sizing of the intermittent power sources total capacities operating in the power system.

\section{Other benefits of $P V$ power systems integration}

Integration of PV power systems as well as other small-scale distributed power generation systems into the public grid has not only negative but also positive consequences for the power system.

Energy security or hedging value is one of them. The PV power plant is producing electricity at least $25-30$ (as predicted, soon will be 40 ) years after its installation independently of the situation in fuel market because it does not use any fuel. This is considered a positive aspect of energy security. This independence from fuel and all associated problems is evaluated in the EU from 1.5 to 3.1 EURct/kWh [24].

Reduction of power losses in the public grid is another positive feature of PV power plants integration. A significant part of power produced by large-scale power plants is being lost in electricity supply lines during the power transmission and distribution across the country. These losses can be avoided when small-scale power sources like PV power plants are distributed close to the electricity consumers. Researchers evaluated the benefit from power losses avoidance in the public grid around 0.5 EURct/kWh [24].

Besides the systems mentioned above, the integrated PV power systems, which are able to operate in the mode of the power island, allow en- hancing reliability of power supply in the regions where blackouts in the public grid are common phenomena. Disruption of electricity supply usually happens in some windy regions of Lithuania every year during storms and hurricanes. Therefore, distributed small-scale power plants of various types could eliminate or substantially reduce financial losses of numerous electricity users in risky localities.

One more benefit from the PV power plants installation is possible: integration of well-balanced optimal capacity of distributed PV and other small-scale RES-based power plants would allow avoiding or delaying of local transformer substation upgrading by increasing its rated power.

\section{Impact of innovations on further development}

Global success of the PV power production technologies is closely related to innovations and technological advances that help to reduce the cost of the PV systems and improve their efficiency. Nowadays, a great potential is proved by the innovative solar panels with holographic concentrators [3]. This type of PV modules is currently under investigation in the International Company Solar Bankers based in the USA. Their patented nanostructured diffractive lens helps to achieve $28 \%$ efficiency from conventional silicon based PV modules [3]. The lens concentrates light onto a small active area, and therefore, a significantly smaller amount of silicon is needed. This causes major savings, since silicon production requires huge amounts of energy. What is more, the holographic optic concentrates only on the desirable wavelengths of the light and does not affect ranges that are not needed, such as the infrared spectrum. This helps to avoid overheating that causes considerable efficiency losses, especially in regions with a high direct solar irradiation. The optic is also very thin and can be produced by using printing technologies allowing economically efficient duplication. Therefore, these solar modules should cost significantly less even if compared to China manufacturers' products.

One more promising innovation is provided by Morgan Solar Company. This company manufactures solar modules based on high-performance triple-junction (III-V) photovoltaic cells that 
accept a wider range of the solar spectrum and have a more consistent power output under high temperatures [4]. Morgan Solar announces that their solar modules have over $29 \%$ active area efficiency and are optimized for large-scale, ground-mounted applications in hot environments. A good efficiency are achieved by using light-guiding lenses that are made from cheap glass and acrylic components. Similarities of Morgan Solar innovation to the above-mentioned technology: this optic is also thin, has well-established manufacturing technology and is cost-effective. A unique solar module configuration and light-concentrating optics allow using only a small amount of costly PV materials. Production of the innovative solar panels Morgan Solar Company begins in 2014.

Thus, the solar panels invented in both companies offer a lower levelized cost of electricity due to their enhanced efficiency and substantially reduced price that will result in further decrease of the investment costs. Apart from the innovations described above, there are dozens of other innovations, improvements and inventions regarding other varieties of PV power conversion technologies.

In general, the cost of PV power systems is constantly falling down not only due to the innovations but also because of the following factors:

- Increasing efficiency of PV modules,

- Optimisation of production,

- Economy of scale,

- Extended lifetime of PV systems,

- Development of standards and specifications.

Substantial cost reduction of PV power systems is also reflected in the ten year objectives for PV technology roadmap projected by the European Photovoltaic Industry Association (EPIA). The following main targets are calculated in this roadmap for 2020 [24]:

- Typical efficiency of PV module

- crystalline silicon 18-23\%,

- thin films $10-16 \%$,

- with concentrators 30-35\%,

- inverter lifetime >25 years,

- module lifetime 35-40 years,

- system energy payback time 0.5 year.

All the measures mentioned above have a positive impact on the decline of PV power system costs, which are continually reducing during the last years with an average rate $5-7 \%$ per year.

\section{Possibilities of reduction of integration costs}

The best way to reduce integration costs of PV power plants is to use the generated power first of all for feeding the local loads. In this case, only surplus of electricity not used locally is supplied into the power system grid. Capacities of such PV power plants should depend on the installed total rated power of local electrical loads and amounts of their yearly produced energy should not substantially differ from the total yearly consumed power. Therefore, capacities of PVPP will be different for a private house, apartment building, a small or medium enterprise, a college or university and for a big company or the microgrid. The rest of the produced energy not consumed by local loads is mostly consumed by the neighbouring electrical loads in the boundaries of a local transformer substation, and any service of the transmission grid in this case is not necessary. Thus, solar power integration costs will be minimal in this case. The transmission grid is used only in the case of multimegawatt or gigawatt PV power plants, which are already being built in some countries.

Anyway, some part of energy produced at the PV power plant will be supplied into the power system electric grid, and it will have some impact on the power balancing process. Expenditures for all possible intermittent powers balancing including variable loads can be reduced by choosing proper tools for power balancing. The most cost-efficient environmental friendly tools for power balancing in the power system grid are hydro electric power plants (for medium-term applications), hydro electric pumped storage power plants (for long-term applications) [26], and in the nearest future - fuel cells PEMFC and SOFC [27]. Additional hydro electric power generation set / pump of controlled speed is intended to install in the Kruonis Hydro Pumped Power Plant in the nearest future. Another two hydro electric power generation sets / pumps of smaller capacity (100 MW and $50 \mathrm{MW}$ ) and constant speed could also be installed on the presently free water pipelines additionally in order to have more flexibility for power balancing in the power system. Possibly one more hydro electric 
power generation set / pump having capacity $25 \mathrm{MW}$ could be useful for power balancing purpose in order to utilize the last presently free water pipe line and to enhance flexibility of power balancing once more.

Building of one or two new hydro electric power plants on the Nemunas River between Kaunas and Druskininkai for power balancing purposes also could be reconsidered. We suppose that it would not cause much additional environmental losses if the dam would not be high, because the river is already dammed at Kaunas and Grodno. However, it would be useful for green power production development in Lithuania, including the application of new hydro electric power plants for intermittent power balancing in the power grid. New hydro electric power plant capacity $20 \mathrm{MW}(17.8 \mathrm{MW})$ was built recently (2008-2012) on the Nemunas River close to Grodno city in Belarus. Another hydro electric power plant on the same river is under construction now in Belarus, very close to the Lithuanian border. It would be purposeful to research a possibility to build a new hydro electric power plant on this river upstream from Kaunas.

Usage of powerful thermal power plants running on fossil fuels for power balancing would be expedient to avoid because they are not cost-effective and environmentally friendly, they have substantial inertia and significant power losses when their output power is adjustable. The most efficient operating mode for them is available at the rated capacity without variations of output power.

\section{RESULTS OF ANALYSIS AND DISCUSSION}

Analysis of broad data presented in this paper on economic and environmental benefits from the PV power plants installation including favourable investment costs, low operation and maintenance costs, good average full life-cycle levelized cost of produced electricity and one of the best in power production sector external costs indicate that $\mathrm{PV}$ power plants can definitely take a certain part in future electricity generation mix practically in any country including Baltic countries as well. Universal accessibility, maturity of the technology and huge untapped technical potential existing in the major part of the world additionally prompts to implement this idea. Some EU countries, which have the same or similar solar energy resources, have done this already. New Lithuanian strategy for energy development encourages expansion of diversity of primary energy sources and utilization of local renewable energy sources; however, PV power production technologies were always neglected and underestimated in all past strategies. Traditionally they are neglected and underestimated in the newest strategy as well despite of a huge leap of progress made in the photovoltaic power production sector during the past five years.

We consider that every electricity user should have a right to install a roof-top or limited scale ground-based grid-connected PV power plant at request. In other words, every user should be allowed to produce electricity for oneself. Therefore, no target has to be set for the roof-top PV power plants. They could be designed for feeding domestic appliances of private houses, enterprises, institutions and in the nearest future - electrical vehicles (EV). Typical capacity of the roof-top PVPP private home could be around $10 \mathrm{~kW}$. But electricity users of larger scale such as apartment buildings, offices, schools, universities, companies and other institutions should be allowed to install PV power plants of larger capacity according to their yearly electric power demands. The best option for power metering would be a bi-directional power meter and the same tariffs for the electricity consumed from the grid and supplied into the grid without any support.

Installation of utility-scale PV power plants is also expedient because local solar energy resources are sufficient for this. Optimal capacities of large-scale PV power plants and sites for their installation have to be determined by the utilities.

Advantages and indicators of PV power plants mentioned in the analysis given above allow concluding that this technology of electricity production is underestimated in the Baltic States because understanding in this area between the decision makers is not updated. Owners of already built small-scale (mostly $30 \mathrm{kWp}$ ) PV power plants in Lithuania affirm that LCOE of the produced power makes up around 0.20 LTL what is more than twice less expensive than electricity 
sold from the public grid (0.474 LTL). This is a good motivation to install the PV power plants for meeting local electricity needs, and it would be useful for everybody. Housekeepers, institutions of education have much more reasonable needs than paying costly bills for heating and electricity. Local consumption rates in the Baltic countries market can be increased when bills for energy are cut. Businessmen could significantly enhance their competitiveness due to the reduced expenditures on energy, especially when energy-intensive technologies are used. Thus, there are many motivations to invest in such promising projects as $\mathrm{PV}$ power plants, especially when interest rates in the EU banks are close to zero.

Majority of researchers and industrialists working in the field of PV technologies forecast that solar power plants soon will be the main players in the energy market in the major part of the world [7-9] as it was predicted on repeated occasions in the past.

\section{CONCLUSIONS}

1. During the last years, PV power production is becoming a competitive technology, and presently it is reaching the grid parity in around 80 countries, which have substantial solar energy resources and high price of electricity.

2. Seven EU countries, which have the same or similar solar irradiations like the Baltic countries, have already (2013) installed substantial cumulative capacities of PV power plants (from 0.52 to $3 \mathrm{GW}$, see Table 2).

3. Life-cycle carbon intensity of PV power plants is presently many times smaller in comparison to power plants running on fossil fuels and has a trend to decrease in the nearest future due to the decreasing quantities of silicon used for the PV cells production, what is making this technology one of the most friendly technologies to the environment.

4. Investment expenditures, operation and maintenance costs, average full life-cycle cost for the produced energy unit of the PV power plants are already among the best in the category of power production technologies and, according to the prognoses, they will keep dropping.

5. Additional costs of PV power plants integration into the grid of the power system are not so considerable and they can be significantly reduced due to consuming of bulk electricity by local loads before its supplying into the grid.

6. PV power plants have low external costs, which have a trend to decrease due to the innovations, which also allow expecting of a new wave of considerable solar power price reduction and making this technology even more cost-effective and attractive.

7. Installation of the PV power plants of the optimal total capacity in the main grid is also expedient if substantial capacities of WTs are already installed in the state's power system, because both cumulative intermittent power sources properly complement one another in regard to the significantly better monthly power production equability, what results in reducing of the expenditures for power balancing.

8. The findings of the analysis allow concluding that possibilities of the PV power further development in general are excellent and very promising even in the high latitude countries.

Received 9 June 2014

Accepted 30 October 2014

\section{References}

1. Worldwide electricity production from renewable energy sources. Fifteenth Inventory - Edition 2013. http://www.energies-renouvelables.org/observ-er/ html/inventaire/Eng/sommaire.asp/\#chapitre3

2. US Department of Energy. 2012 Renewable Energy Data Book. October 2013. 127 p.

3. Game-Changing Innovation for the Solar Industry. Dresden, Germany: Apollon GmbH \& Co. KG; Arizona, USA: Solar Bankers LLC, 2013. http://www.medienkontor.net/de/news/news-detailansicht/article/game-changing-innovation-for-the-solar-industry.htm]

4. Light-guided solar panel and method of fabrication, Patent US 7873257 B, 2011.01.18.

5. 'World must triple nuclear and renewable energy' - United Nations. April 14, 2014. http://rt.com/ business/triple-nuclear-renewable-energy-336/

6. Climate Change 2014: Impacts, Adaptation, and Vulnerability. Summary for Policymakers. Intergovernmental Panel on Climate Change (IPCC). WMO, UNEP, 2014. 32 p. 
7. Masson G., Latour M., Rekinger M., et al. Global Market Outlook for Photovoltaics 2013-2017. Brussels, Belgium: European Photovoltaic Industry Association (EPIA), 2013. 60 p.

8. Half of the Global Energy Supply from Renewables in 2040. Brussels: European Renewable Energy Council (EREC), May 2004. 16 p.

9. $45 \%$ BY 2030. Towards a truly sustainable energy system in EU. Brussels: European Renewable Energy Council (EREC), May 2004. 32 p.

10. Masson G. Snapshot of Global PV 1992-2013. Preliminary Trends Information from the IEA PVPS Programme. PVPS Report. 2014. 16 p.

11. LITGRID. Ataskaitos apie energija, kurios gamybai naudojami atsinaujinantieji energijos ištekliai. http://www.litgrid.eu/index.php/paslaugos/ kilmes-garantiju-suteikimas/ataskaitos/563

12. The State of Renewable Energies in Europe. Edition 2013. 13th EurObserv'ER Report. 103 p. http:// www.energies-renouvelables.org/observ-er/stat baro/barobilan/barobilan13-gb.pdf

13. Solar Energy in the EU. http://en.wikipedia.org/ wiki/Solar_energy_in_the_European_Union

14. Adomavičius V., Pušinaitis L. Analysis of the RES-based power production growth rates in Lithuania in regard to the EU targets for 2020. Proceedings of International Conference ECT2014. Kaunas: KTU, 2014. P. 132-137.

15. Edenhofer O., Pichs-Madruga R., Sokona Y., et al. Renewable Energy Sources and Climate Change Mitigation. Summary for Policymakers and Technical Summary. Potsdam Institute for Climate Impact Research (PIK), 2012. 246 p.

16. Electricity Production from Solar and Wind in Germany in 2013. Fraunhofer Institute for Solar Energy Systems ISE, 9 January 2014. 263 p.

17. Edenhofer O., Seyboth K., Creutzig F., Schlomer S. On the sustainability of renewable ener- gy sources. Annual Review of Environment and Sources. 2013. Vol. 38. P. 169-202.

18. International Energy Agency (IEA). Redrawing the Energy-Climate Map. World Energy Outlook Special Report. Paris: Corlet, June 2013. 124 p.

19. Konstantin P. Praxisbuch Energiewirtschaft: Energieumwandlung, - ransport und - beschaffung im liberalisierten Markt (VDI-Buch). Berlin: Springer, 2013. $551 \mathrm{p}$.

20. Kost C., Mayer J. N., et al. Levelized Cost of Electricity. Renewable Energy Technologies. Study. Fraunhofer Institute for Solar Energy Systems (ISE), November 2013. $47 \mathrm{p}$.

21. Tarjanne R., Kivistö A. Comparison of Electricity Generation Costs. Research Report EN A-56. Lappeenranta University of Technology, 2008. 28 p.

22. Štreimikienė D., Ališauskaitè-Šeškienė I. Elektros energijos gamybos šaltinių išorinių kaštų Lietuvoje vertinimas. Energetika. 2013. T. 59. Nr. 1. P. 11-19.

23. Štreimikienė D., Mikalauskienè A., Zaikienè J. Elektros energijos gamybos technologiju darnumo vertinimas, taikant integruotus rodiklius. Energetika. 2011. T. 57. Nr. 3. P. 141-153.

24. Solar Photovoltaic Electricity Empowering the World. Brussels: European Photovoltaic Association (EPIA), 2011. 100 p.

25. Chabot B. Analysis of 13 years of successful PV development in Germany under the EEG with a focus on 2013. Renewables International. March 2014. 55 p.

26. Adomavičius V. Mažosios atsinaujinančiuju ištekliu energijos sistemos. Kaunas: Technologija, 2013. $288 \mathrm{p}$.

27. Energinet. Technology Data for Energy Plants. DK Styrelsen, May 2012. 211 p. 
Vytautas Adomavičius, Mantas Kaminickas

\section{SAULĖS ENERGETIKOS TOLIMESNĖS} PLÉTROS GALIMYBIŲ ANALIZE்

\section{Santrauka}

Spartus saulès fotoelementų rinkos augimas bei kiti ekonominiai ir techniniai veiksniai lemia spartų nuolatinį saulès elektrinių ịrengimo kainos mažejimą. Dèl šios priežasties saulès elektrinès jau tampa ekonomiškai patrauklios ir pasaulio regionuose, kur daugiametè vidutinè saulès ekspozicija horizontaliose plokštumose sudaro $900-1100 \mathrm{kWh} / \mathrm{m}^{2}$. Straipsnyje analizuojamas tolimesnès saulès energetikos pletros galimybès ir saulès elektrinių tinkamumas elektros energijai gaminti aukštųjų geografinių platumų šalyse (ir Baltijos valstybėse). Nagrinėjami kitų šalių pasiekimai, saulès energetikos plètros tendencijos Europoje ir pasaulyje, vertinamos šalys, turinčios panašius saulès išteklius kaip ir Baltijos regionas. Saulès elektrinių teigiami bruožai išryškinami palyginant ịvairių tipų elektrinių energijos gamybos, integravimo ir išorinius kaštus, ìvairių technologijų ịtaką aplinkos taršai bei klima- to kaitai. Realios tolesnio saulès elektrinių ịrengimo kainų mažèjimo galimybès grindžiamos laboratorijose jau išbandytomis inovacijomis, kurios šiuo metu diegiamos i gamybą. Straipsnyje taip pat aptariami galimi būdai, leidžiantys sumažinti saulès elektrinèse pagamintos energijos integravimo $\mathfrak{i}$ energetikos sistemos elektros tinklą kainą. Vienas iš jų - ivvairių atsinaujinančiųjų energijos išteklių (saulès, vejjo ir hidroenergijos) elektrinių optimalių galių parinkimas ir jų darbo derinimas. Pateikiama išvada, jog pasaulyje yra puikios saulès energetikos plètros galimybès, o aukštųjų geografinių platumų šalyse, pavyzdžiui, Lietuvoje ir kitose Baltijos valstybèse, jau netolimoje ateityje turètų jos sudaryti gana reikšmingą elektros energetikos sistemos galios dalị, nes saulès spinduliuote turi patị didžiausią energinị potencialą, lengviausiai prieinama, gamybos būdas - vienas iš efektyviausių ir ekologiškai švariausių dabar žinomų elektros energijos gamybos būdų.

Raktažodžiai: atsinaujinantieji energijos ištekliai, saulès elektrinès, plètros tendencijos, energijos gamybos kaštai, integravimo kaštai, išoriniai kaštai, klimato kaita 